\title{
Quality of Meat and Some Meat Products Manufactured at SC Ferma Zootehnica SRL Baia Mare
}

\author{
Camelia RĂDUCU ${ }^{1}$, Vioara MIREŞAN ${ }^{1}$, Aurelia COROIAN ${ }^{1}$, Dana PUSTA ${ }^{2}$, Simona PAŞCALĂU ${ }^{1}$, Cristian \\ COROIAN $^{1}$, Zamfir MARCHIȘ ${ }^{1}$, Luisa ANDRONIE ${ }^{1}$, Daniel COCAN ${ }^{1 *}$ \\ ${ }^{1}$ Faculty of Animal Science and Biotechnologies, University of Agricultural Sciences and Veterinary \\ Medicine, 3-5 Mănăştur Street, 400372 Cluj-Napoca, Romania \\ ${ }^{2}$ Faculty of Veterinary Medicine, University of Agricultural Sciences and Veterinary Medicine, 3-5 \\ Mănăştur Street, 400372 Cluj-Napoca, Romania \\ *corresponding author, e-mail: daniel.cocan@usamvcluj.ro; cocandaniel@yahoo.com
}

Bulletin UASVM Animal Science and Biotechnologies 75(1)/ 2018

Print ISSN 1843-5262; Electronic ISSN 1843-536X

DOI:10.15835/buasvmcn-asb: 002217

\begin{abstract}
During a period of 6 months beginnings with October 2016 until March 2017, were analysed meat products such as: Haiducesc smoked chest, Premium jambon, as well as semi-smoked assortments: Pork salami, Pintea salami and Pancetta salami obtained at SC. "Ferma Zootehnică" SRL Baia Mare. The results are reported at 100 $\mathrm{g}$ of product and were as follow: Haiducesc smoked chest: $31.87 \%$ water, $3.2 \mathrm{~g}$ salt, $2.51 \mathrm{mg}$ nitrites; Premium jambon: 32.16\% water, $3.38 \mathrm{~g}$ salt, $2.78 \mathrm{mg}$ nitrites; Pork salami: $53.2 \%$ water, $2.13 \mathrm{~g}$ salt, $2.32 \mathrm{mg}$ nitrites; Pintea salami: $51.8 \%$ water, $2.21 \mathrm{~g}$ salt, $2.95 \mathrm{mg}$ nitrites; Pancetta salami: $46.08 \%$ water, $2.21 \mathrm{~g}$ salt, $2.04 \mathrm{mg}$ nitrites. The obtained values fit in the allowed limits of the European norms STAS 6352/1-88 and 6353-85, therefore the products obtained are very good quality.
\end{abstract}

Keywords: meat, quality, meat products

\section{INTRODUCTION}

Being the world's most demanding of all animal products, meat, due to its high protein level, is an indicator of a person's living standards and lifestyle. Year-on-year there is an increase in consumption and meat production, both worldwide and nationally (Banu et al., 2007). This basic food has a plastic, energetic role, supports the growth, regeneration and maintenance of tissues and helps in the formation of antibodies in the body (Banu, 2008), so necessary for protection against diseases and infections. The technology of meat industrialization has been particularly developed and continuous improvement is being considered for the realization of high quality products. The hygiene of food of animal origin requires severe processing conditions, so as not to harm consumers' health (Laslo et al., 2008) and not to lose the nutritious qualities of meat and preparations.

\section{MATERIALS AND METHODS}

The research took place at SC "Ferma Zootehnică" SRL Baia Mare,during a period of 6 months beginnings with October 2016 until March 2017. The quality of the products obtained at the meat processing unit was appreciated in the factory's laboratory by taking 10 samples of the following items: meat specialties: Haiducesc smoked chest, Premium jambon, as well as semismoked assortments: Pork salami, Pintea salami, Pancetta salami.

For testing the quality of meat specialties we determined the content of water, salt and 


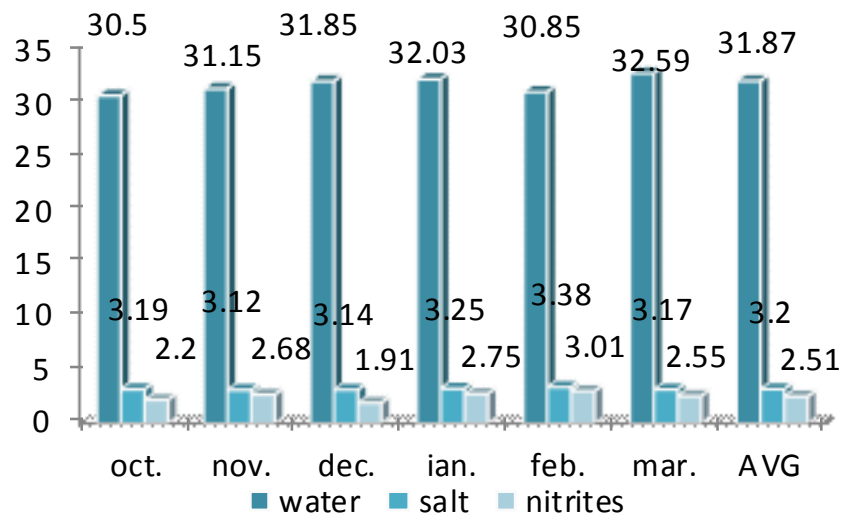

Figure 1. Variation of quality parameters to the Haiducesc smoked chest

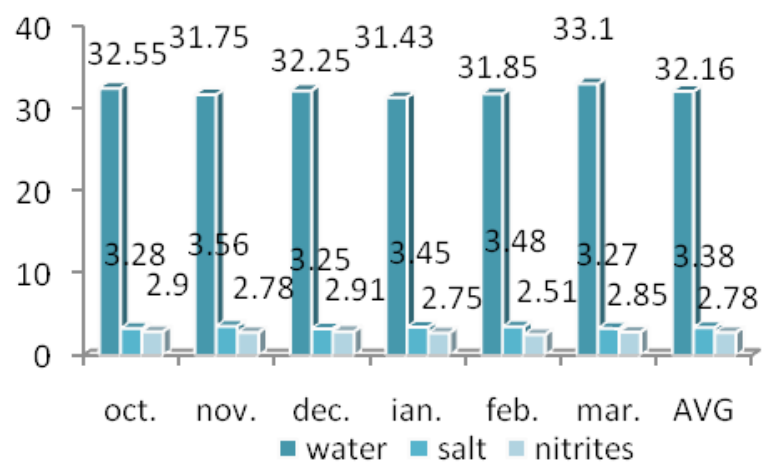

Figure 2. Variation of quality parameters to the Premium jambon

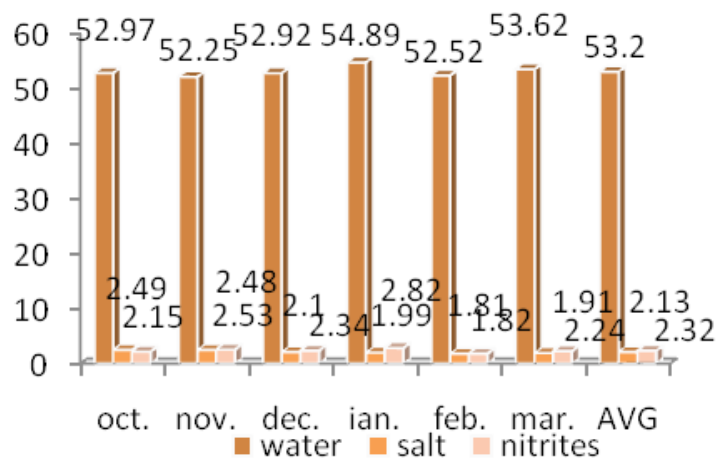

Figure 3. Variation of quality parameters to the Pork salami

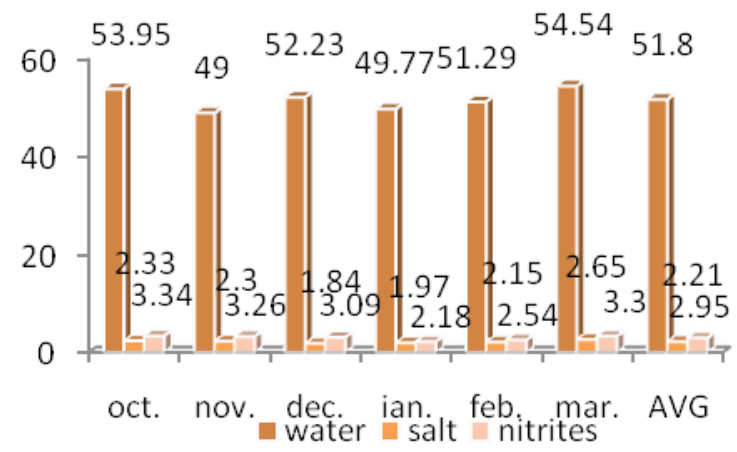

Figure 4. Variation of quality parameters to the Pintea salami

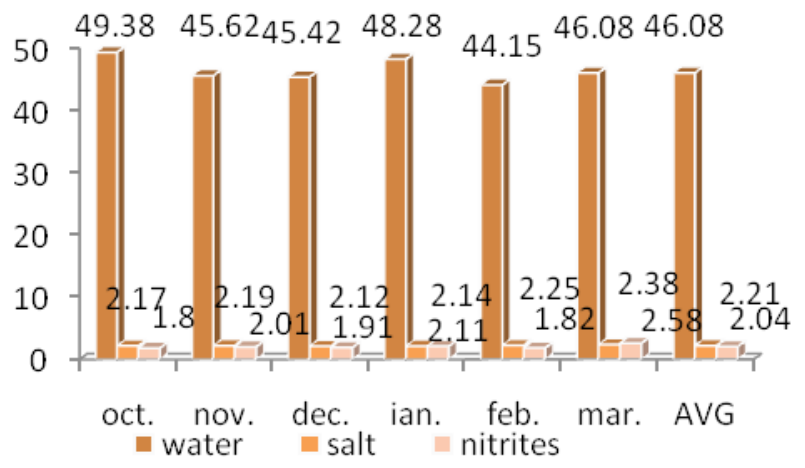

Figure 5. Variation of quality parameters to the Pancetta salami

nitrite. The water content was determinated by drying the samples at the oven for 4-5 hours at a temperature of $105^{\circ} \mathrm{C}$ according Iurca (2006) protocol, salt concentration was determinated by Mohr metod according Iurca (2006) protocol and nitrates were determinated by Griess metod. The raw materials used in the manufacture of the preparations were as follow: pork meat, water, salt shuger, food gelatin, sodium, potassium, ascorbic acid, polyphosphates, flavorings, spices, essential oils, flavor enhancers, cultures of microorganisms, membrane.

\section{RESULTS AND DISCUSSIONS}

After the performed analysis, these values regarding the content of water, salt and nitrites, the results are reported at $100 \mathrm{~g}$ of product and were as follow: Haiducesc smoked chest (Figure. 1): $31.87 \%$ water, $3.2 \mathrm{~g}$ salt, $2.51 \mathrm{mg}$ nitrites, the obtained values for this product fit in the allowed 
limits of the European norms STAS 6352/1-88 and 6353-85 of 40\% water, $9 \mathrm{~g}$ salt, $7 \mathrm{mg}$ nitrites.

Premium jambon (Figure 2): 32.16\% water, $3.38 \mathrm{~g}$ salt, $2.78 \mathrm{mg}$ nitrites, the obtained values for this product fit in the allowed limits of the European norms STAS 6352/1-88 and 6353-85 of $40 \%$ water, 9 g salt, 7 mg nitrites.

Pork salami (Figure 3): 53.2\% water, $2.13 \mathrm{~g}$ salt, $2.32 \mathrm{mg}$ nitrites; the obtained values fit in the allowed limits STAS 6352/1-88 and 6353-85 of 56-58\% water, $3 \mathrm{~g}$ salt and $7 \mathrm{mg}$ nitrites.

Pintea salami (Figure 4): 51.8\% water, $2.21 \mathrm{~g}$ salt, $2.95 \mathrm{mg}$ nitrites; the obtained values for this product fit in the allowed limits STAS 6352/1-88 and $6353-85$ of of $68 \%$ water, $3 \mathrm{~g}$ salt and $7 \mathrm{mg}$ nitrites.

Pancetta salami (Figure 5): 46.08\% water, $2.21 \mathrm{~g}$ salt, $2.04 \mathrm{mg}$ nitrites, the obtained values for this product fit in the allowed limits STAS $6352 / 1-88$ and $6353-85$ of $45 \%$ water, 3 g salt and $7 \mathrm{mg}$ nitrites.

\section{CONCLUSIONS}

The raw material used to prepare the preparations corresponds physically, chemically and organoleptically.

Physicochemical preparations during this study period meet the requirements of existing STAS regarding the amount of water, salt, and nitrite.

As a result of the qualitative analyzes performed on the products obtained at this unit, was found that the base material used to obtain these meat products, has a good quality from all points of view and it fits in the allowed limits of the European norms. After this evaluation, it was concluded the fact that the products obtained at SC Ferma Zootehnica SRL, are very good quality.

\section{REFERENCES}

1. Banu C (2007). Calitatea şi controlul calităţii produselor alimentare. Ed. AGIR, București.

2. Banu C (2008). Suveranitate, securitate și siguranța alimentară. Ed. ASAB, București.

3. Iurca IM (2006). Procesarea și controlul calității produselor acvacole. Ed. Academic Press, Cluj-Napoca.

4. Laslo C, Mureșan C, Jimborean M, Suharoschi R (2008). Examenul de laborator al produselor alimentare de origine animală, Indrumător de lucrări practice. Editura AcademicPres, Cluj-Napoca. 